\title{
Serum Immunoglobulins and Coproantibody Formation in Infants after Artificial Intestinal Colonization with Escherichia coli 083 and Oral Lysozyme Administration
}

\author{
R. Lodinová ${ }^{[45]}$, V. JoUja, AND V. WAgner \\ Institute for the Care of Mother and Child, Prague-Podolí, Czechoslovakia
}

Extract

In infants colonized with a nonenteropathogenic strain, Escherichia coli 083, the strain was detected in the stool from the 2nd day after oral administration and remained in predominance during 16 weeks. The serum antibody against E. coli 083 increased rapidly during the 4th week in breast-fed and in formula-fed, colonized infants and remained significantly higher for 16 weeks when compared with control subjects. Lysozyme did not influence the serum immunoglobulin levels.

The production of hemagglutinating coproantibody against E. coli 083 started in the 2 nd week and remained statistically significant up to the 6th week in breast-fed infants. In bottle-fed, colonized infants the increase of the antibody level is significantly higher between the 4th and 16th week when compared with control subjects. Immunoglobulin $\mathrm{M}$ ( $\operatorname{Ig} \mathrm{M}$ ) was detected in bottle-fed infants only.

In breast-fed, colonized infants and in control subjects, a high level of secretory immunoglobulin A ( $\operatorname{IgA}$ ) was found between the 1st and 8th week. In bottle-fed, colonized infants the increase of secretory $\operatorname{IgA}$ started from the 4 th week and stayed significantly higher in the 6 th, $12 \mathrm{th}$, and 16th week. No immunoglobulin G (IgG) at all was found in stool filtrates.

Lysozyme did not influence the production of serum immunoglobulins, coproantibody, and secretory IgA.

The artificial oral colonization induced a higher formation of secretory IgA in the intestinal mucosa. This effect can be detected in bottle-fed infants only, as the infants own production of $\operatorname{IgA}$ is masked by $\operatorname{IgA}$ passively transferred from maternal milk during breast feeding.

\section{Speculation}

Oral colonization of neonates with a nonenteropathogenic $E$. coli may provide a better state of immunity for artificially fed infants. The unusual ability of the $E$. coli 083 strain to predominate in the stool for prolonged periods could be used as a therapeutic approach for enteric infections caused by antibiotic-resistant bacteria and for individuals with altered stool flora due to prolonged antimicrobial therapy.

Colonization experiments such as these confirm that the immune responses of human neonates are a useful model for the study of this important developmental phenomenon. 


\section{Introduction}

After intrauterine life in a sterile environment, the newborn infant comes into contact with a variety of microorganisms. As shown by experiments in germ-free animals, this contact with organisms exerts a profound effect upon the development of immune reactivity [35]. Even though the human fetus produces a small amount of immunoglobulins, the main protection during the first weeks of life is provided by maternal antibodies.

The levels of all immunoglobulins are comparatively low [34], and the infants are very sensitive to enteral and parenteral infections, especially those caused by gram-negative bacteria. Human colostrum and milk contain high amounts of IgA and less IgG and IgM [32]. Breast-fed infants obtain from colostrum, and later from milk, IgA-containing antibodies against all infections which the mother has met previously. Milk IgA could be detected in effective amounts in the stool of breast-fed infants, although it could not be found in feces of bottle-fed infants [16, 17].

Lysozyme is another component of breast milk that is capable of altering the microbial flora as well as mediating a beneficial effect upon enteric infection. Lysozyme is present in human milk and is absent in cow's milk [6, 20].

The importance of the intestinal flora, which represent a strong antigenic stimulus for the whole organism, has been confirmed by many experimental studies. It influences the development of immune reactions and preforms them, to some extent, for the rest of life [35].

In a study dating back to 1927, Besredka [2] developed a concept of local immunity on the surface of mucous membranes. However, he did not postulate an immunity mediated by antibodies. In 1938 Torikata and Imaizumi [37] demonstrated opsonins in the intestine after oral or parenteral vaccination. It was found subsequently that many different external secretions bathing mucous surface contained a predominance of $\operatorname{IgA}$ and smaller concentrations of $\operatorname{IgM}, \operatorname{IgG}$, and $\operatorname{IgD}$ [36].

Antibodies produced locally by the intestinal $\mathrm{mu}$ cosa were named coproantibodies by Burrows et al. [3]. Coproantibody formation was shown after experimental immunization in laboratory animals $[7,18]$ and natural infection and vaccination in man $[27,29]$. Oral vaccination in adults and infants induced higher titers of coproantibodies than did serum antibodies [10, 15].
Fluorescent antibody studies show that most Ig-containing cells of the intestinal submucosa contain IgA, a lesser number of cells contain IgM and a very low number of cells contain $\operatorname{IgG}$ [4]. Secretory $\operatorname{IgA}$ contains one more polypeptide chain (secretory component), synthesized by the intestinal epithelial cell, than serum IgA [13, 38]. Secretory IgA also differs from serum $\operatorname{IgA}$ in its greater resistance to the degradative effect of proteolytic enzymes [33].

There are unique factors in the neonate which may affect the local intestinal response. In the neonate, the number of Ig-producing cells in the submucosa and the concentration of secretory immunoglobulins is very low [5].

In our previous papers [21, 22], we demonstrated that after artificial oral colonization with a nonenteropathogenic strain, E. coli 083, this strain remained predominant for several weeks when compared with $E$. coli strains acquired spontaneously from the environment. E. coli 083 evoked an earlier and higher serum antibody response in full term as well as in premature infants than the other E. coli strains [23].

In this study the effect of oral colonization with a nonenteropathogenic E. coli, strain 083, and feeding with lysozyme in breast-fed and bottle-fed infants upon the production of serum and secretory immunoglobulins and antibodies was studied.

\section{Methods}

All infants under long term investigation were delivered in our institute and kept in the department for healthy infants from birth until the age of 6 months.

We started with 14 artificially fed infants. They were colonized with E. coli type 083. A suspension prepared from a 24 -hr culture containing $5 \times 10^{s}$ organisms $/ \mathrm{ml}$ was administered during the first $24 \mathrm{hr}$ after birth and again 3 times a week for 3 successire weeks. The suspension was prepared freshly every day and 10 colonies from each petri clish were tested for specificity. The $S$ phase was proved by boiling and with acriflavin. The stool specimens were cultured and $E$. coli colonies were tested with $E$. coli antiserum to serotype 083 for specificity.

Later, eight breast-fed and nine artificially fed infants were colonized in the same way.

Lysozyme, $10 \mathrm{mg} / 100 \mathrm{ml}$, was added to the milk formula of 11 bottle-fed infants for a 2-month period [40]. The control gxoups consisted of 11 breastfed and 10 artificially fed infants. The bottle-fed infants were fed with humanized cow milk formula [41]. 
Blood samples were drawn from the mothers and from each child before the colonization. Additional blood and stool samples were taken during the 1st and 2nd week after colonization, after which the samples were taken every 2 weeks for a 24-week period. Stool samples were collected under sterile conditions. Sera were stored at $-15^{\circ}$ and stool samples were stored on Dry Ice. Antibodies against E. coli 083 were determined by a hemagglutination technique on microtitrator plates according to the method of Neter et al. [25].

Concentrations of $\operatorname{IgG}, \operatorname{IgM}$, and $\operatorname{IgA}$ in the sera were first determined quantitatively by double immunodiffusion technique in a micromodification of the Ouchterlony method using monospecific antisera [42] in three dilutions and normal human serum Behringwerke. Where the immunoglobulins were present, the concentration was determined quantitatively by radial immunodiffusion according to the method of Fahey and Mckelvey [8]. The serum concentrations were expressed in milligrams per milliliter. Stool samples collected under sterile technique were mixed thoroughly and diluted to 10 volumes of sterile saline with a vortex for $3 \mathrm{~min}$ and centrifuged for $30 \mathrm{~min}$ at $5^{\circ}$ at 10,000 rpm and the supernatant passed through Millipore filters (type $\mathrm{HF}$, pore sizes $5 \mu \mathrm{m}$ and $22 \mu \mathrm{m}$ ). The filtered supernatant, assayed for sterility, was then studied for $E$. coli 083 antibody by passive hemagglutination technique and for $\operatorname{IgG}, \operatorname{IgM}, \operatorname{IgA}, \alpha$-2-macroglobulin, ceruloplasmin, transferrin, albumin, $\beta$-lipoprotein, and Bence-Jones proteins, types $\mathrm{K}$ and $\mathrm{L}$, by Ouchterlony's method. When Ig were detected they were measured quantitatively by radial immunodiffusion technique. A highly purified colostral IgA [43] was used as reference standard for the measurement of stool filtrate IgA. The final concentrations of Ig were expressed in milligrams of protein per gram of stool.

For statistical evaluation, the one-way layout analysis of variance, the method of Scheffe, and the Fisher's test [9] were used [30].

\section{Results}

In the first group of infants the strain E. coli 083 was detected in the stool from the 2nd day after oral administration and remained in predominance during the whole time of investigation. Until 14 weeks it was the only $E$. coli strain found in the stool (Fig. 1).

Serum antibody against $E$. coli 083 was detected in all infants in a low titer from the lst week of life, as shown in Figure 2. The titer increased rapidly during the 4th week in breast-fed and formula-fed, colonized
Table I. Serum-hemagglutinating antibody against Escherichia coli $083^{1}$

\begin{tabular}{|c|c|c|c|c|c|c|c|}
\hline Group & $\vec{x}$ & SE: & $P$ & Group & $\vec{x}$ & SE: & $P$ \\
\hline \multicolumn{4}{|c|}{1 week } & \multicolumn{4}{|c|}{2 weeks } \\
\hline$a$ & 2.63 & 0.41 & & $a$ & 3.50 & 0.60 & \\
\hline$b$ & 3.33 & 0.67 & & $b$ & 3.29 & 0.84 & \\
\hline$c$ & 2.20 & 0.58 & & $c$ & 3.09 & 0.46 & \\
\hline$d$ & 3.00 & 0.38 & & $d$ & 1.80 & 0.80 & \\
\hline$e$ & 2.80 & 0.86 & & $e$ & 3.11 & 1.08 & \\
\hline \multicolumn{4}{|c|}{4 weeks } & \multicolumn{4}{|c|}{6 weeks } \\
\hline$a$ & 5.88 & 0.76 & $\begin{array}{l}a / e \\
P<0.05\end{array}$ & $a$ & 5.50 & 0.56 & $\begin{array}{l}a / e \\
P<0.05\end{array}$ \\
\hline$b$ & 5.00 & 0.41 & & $b$ & 4.89 & 0.54 & $\begin{array}{l}b / e \\
P<0.05\end{array}$ \\
\hline$c$ & 2.81 & 0.68 & & $c$ & 2.72 & 0.38 & \\
\hline$d$ & 3.00 & 0.82 & & $d$ & 3.13 & 0.54 & \\
\hline$e$ & 3.27 & 0.80 & & $e$ & 2.45 & 0.62 & \\
\hline \multicolumn{4}{|c|}{8 weeks } & \multicolumn{4}{|c|}{10 weeks } \\
\hline$a$ & 5.29 & 0.51 & $\begin{array}{l}a / e \\
P<0.05\end{array}$ & $a$ & 4.57 & 1.16 & \\
\hline$b$ & 4.78 & 0.52 & $\begin{array}{l}b / e \\
P<0.05\end{array}$ & $b$ & 4.63 & 0.68 & \\
\hline c & 2.90 & 0.84 & $\begin{array}{l}a / d \\
p<0.05\end{array}$ & c & 3.40 & 0.87 & \\
\hline$d$ & 2.78 & 0.40 & & $d$ & 3.00 & 0.36 & \\
\hline$e$ & 2.81 & 0.53 & & $e$ & 2.54 & 0.65 & \\
\hline \multicolumn{4}{|c|}{12 weeks } & \multicolumn{4}{|c|}{14 wecks } \\
\hline$a$ & 5.00 & 0.26 & $\begin{array}{l}a / e \\
P<0.05\end{array}$ & $a$ & 5.29 & 0.41 & \\
\hline$b$ & 4.11 & 0.66 & & $b$ & 4.63 & 0.53 & \\
\hline$c$ & 3.00 & 0.73 & & $c$ & 2.80 & 0.71 & \\
\hline$d$ & 3.44 & 0.42 & & $d$ & 3.67 & 0.50 & \\
\hline$e$ & 2.72 & 0.37 & & $e$ & 3.50 & 0.67 & \\
\hline \multicolumn{4}{|c|}{16 wceks } & \multicolumn{4}{|c|}{20 wccks } \\
\hline$a$ & 5.43 & 0.29 & $\begin{array}{l}a / c \\
P<0.05\end{array}$ & $a$ & 4.86 & 0.45 & $\begin{array}{l}b / c \\
P<0.05\end{array}$ \\
\hline$b$ & 4.56 & 0.47 & $\begin{array}{l}b / c \\
P<0.01\end{array}$ & $b$ & 5.50 & 0.50 & $\begin{array}{l}d / c \\
P<0.05\end{array}$ \\
\hline$c$ & 3.09 & 0.46 & & $c$ & 2.90 & 0.75 & \\
\hline$d$ & 4.00 & 0.39 & & $d$ & 5.00 & 0.36 & \\
\hline$e$ & 3.81 & 0.49 & & $e$ & 4.10 & 0.54 & \\
\hline \multicolumn{8}{|c|}{24 weeks } \\
\hline$a$ & 5.75 & 0.45 & & & & & \\
\hline$b$ & 4.57 & 0.72 & & & & & \\
\hline$c$ & 3.36 & 0.35 & & & & & \\
\hline$d$ & 5.43 & 0.53 & & & & & \\
\hline$e$ & 4.00 & 0.72 & & & & & \\
\hline
\end{tabular}

${ }_{1} a$ : Breast-fed, colonized infants; $b$ : bottle-fed, colonized infants; $c$ : breast-fed control subjects; $d$ : bottle-fed control subjects; $e:$ lysozyme-fed infants; $\bar{x} ;$ arithmetic mean. For statistical evaluation the one-way layout analysis of variance was used.

infants and remained higher in both colonized groups than in control subjects up to 16 weeks.

In formula-fed control subjects and lysozyme-fed infants a low titer of $E$. coli 083 antibody was present and increased slowly from the 14th week. At 16 weeks the titer reached about the same level as in colonized infants. In breast-fed control subjects, the type 083 antibody remained low to the age of 20 weeks.

There was no significant difference found in the serum IgM levels among all groups (Fig. 3). 
Table II. Stool filtrates: hemagglutinating antibody against Escherichia coli $083^{1}$

\begin{tabular}{|c|c|c|c|c|c|c|c|}
\hline Group & $\bar{x}$ & $\mathrm{SE}$ & $P$ & Group & $\bar{x}$ & $S E$ & $P$ \\
\hline \multicolumn{4}{|c|}{1 week } & \multicolumn{4}{|c|}{2 weeks } \\
\hline$a$ & 1.57 & 0.65 & & $a$ & 2.43 & 0.65 & $\begin{array}{l}d / a \\
P<0.01\end{array}$ \\
\hline$b$ & 1.44 & 0.53 & & $b$ & 1.11 & 0.48 & $\begin{array}{l}e / a \\
P<0.05\end{array}$ \\
\hline$c$ & 0.60 & 0.40 & & $c$ & 1.20 & 0.80 & $\begin{array}{l}b / a \\
P<0.05\end{array}$ \\
\hline$d$ & 0 & 0 & & $d$ & 0 & 0 & \\
\hline$e$ & 0.25 & 0.25 & & $e$ & 0 & 0 & \\
\hline \multicolumn{4}{|c|}{4 weeks } & \multicolumn{4}{|c|}{6 weeks } \\
\hline$a$ & 1.86 & 0.34 & $\begin{array}{l}d / a \\
P<0.05\end{array}$ & $a$ & 2.57 & 0.78 & $\begin{array}{l}d / a \\
P<0.05\end{array}$ \\
\hline$b$ & 2.22 & 0.52 & $\begin{array}{l}e / a \\
P<0.05\end{array}$ & $b$ & 2.44 & 0.65 & $\begin{array}{l}e / a \\
P<0.05\end{array}$ \\
\hline$c$ & 1.36 & 0.39 & $\begin{array}{l}d / b \\
P<0.01\end{array}$ & $c$ & 1.00 & 0.32 & $\begin{array}{l}d / b \\
P<0.05\end{array}$ \\
\hline$d$ & 0.20 & 0.13 & $\begin{array}{l}e / b \\
P<0.01\end{array}$ & $d$ & 0.30 & 0.15 & $\begin{array}{l}e / b \\
P<0.05\end{array}$ \\
\hline$e$ & 0.13 & 0.13 & & $e$ & 0.13 & 0.13 & \\
\hline \multicolumn{4}{|c|}{8 weeks } & \multicolumn{4}{|c|}{10 weeks } \\
\hline$a$ & 1.43 & 0.61 & & $a$ & 0 & 0 & $\begin{array}{l}b / a \\
P<0.01\end{array}$ \\
\hline$b$ & 2.44 & 0.78 & & $b$ & 2.56 & 0.58 & \\
\hline$c$ & 1.00 & 0.45 & & $c$ & 0.60 & 0.60 & \\
\hline$d$ & 0.80 & 0.33 & & $d$ & 0.70 & 0.50 & \\
\hline$e$ & 0.38 & 0.26 & & $e$ & 0.63 & 0.50 & \\
\hline \multicolumn{4}{|c|}{12 wccks } & \multicolumn{4}{|c|}{14 wecks } \\
\hline$a$ & 0.14 & 0.14 & $\begin{array}{l}d / b \\
P<0.01\end{array}$ & $a$ & 0.14 & 0.14 & $\begin{array}{l}d / b \\
P<0.05\end{array}$ \\
\hline$b$ & 3.00 & 0.73 & $\begin{array}{l}e / b \\
P<0.01\end{array}$ & $b$ & 2.89 & 0.56 & $\begin{array}{l}e / b \\
P<0.01\end{array}$ \\
\hline$c$ & 1.00 & 0.55 & $\begin{array}{l}b / a \\
P<0.01\end{array}$ & $c$ & 1.54 & 0.64 & $\begin{array}{l}b / a \\
P<0.05\end{array}$ \\
\hline$d$ & 0.40 & 0.31 & & $d$ & 0.80 & 0.42 & \\
\hline$e$ & 0.13 & 0.13 & & $e$ & 0 & 0 & \\
\hline \multicolumn{4}{|c|}{16 wceks } & \multicolumn{4}{|c|}{20 wceks } \\
\hline$a$ & 0.43 & 0.30 & $\begin{array}{l}d / b \\
P<0.05\end{array}$ & $a$ & 0.14 & 0.14 & \\
\hline$b$ & 2.56 & 0.63 & $\begin{array}{l}e / b \\
P<0.01\end{array}$ & $b$ & 1.89 & 0.61 & \\
\hline$c$ & 0 & 0 & $\begin{array}{l}b / a \\
P<0.05\end{array}$ & $c$ & 0 & 0 & \\
\hline$d$ & 0.60 & 0.31 & $\begin{array}{l}b / c \\
P<0.05\end{array}$ & $d$ & 0.80 & 0.51 & \\
\hline$\varepsilon$ & 0 & 0 & & $e$ & 0 & 0 & \\
\hline \multicolumn{4}{|c|}{24 weeks } & & & & \\
\hline$a$ & 0.29 & 0.29 & & & & & \\
\hline$b$ & 1.33 & 0.75 & & & & & \\
\hline$c$ & 0.60 & 0.60 & & & & & \\
\hline$d$ & 0.10 & 0.10 & & & & & \\
\hline - & 0 & 0 & & & & & \\
\hline
\end{tabular}

1a. Breast-fed, colonized infants; $b$; bottle-fed, colonized infants; $c$ : breast-fed control subjects; $d$ : bottle-fed control subjects; $e$ : lysozyme-fed infants; $\bar{x}$ : arithmetic mean. For statistical evaluation the one-way layout analysis of variance was used [30].

The highest IgG levels were present in the lst to the 2nd week in all infants being passively transferred from the mother. IgG decreased slowly in all infants except for the breast-fed control subjects in whom the titer remained unchanged up to the age of 8 weeks. The difference was not statistically significant. After 10
Table III. Stool filtrates (IgA, milligrams per milliliter)

\begin{tabular}{|c|c|c|c|c|c|c|c|}
\hline Group & $\vec{x}$ & $\mathrm{SE}$ & $P$ & Group & $\bar{x}$ & SE & $P$ \\
\hline & \multicolumn{3}{|c|}{1 week } & \multicolumn{4}{|c|}{2 weeks } \\
\hline$a$ & 22.94 & 10.03 & & $a$ & 29.12 & 10.32 & $\begin{array}{l}a / b \\
P<0.05\end{array}$ \\
\hline$b$ & 4.00 & 2.96 & & $b$ & 1.83 & 1.83 & $\begin{array}{l}a / d \\
P<0.01\end{array}$ \\
\hline$c$ & 8.73 & 4.80 & & $c$ & 24.50 & 9.94 & $\begin{array}{l}a / e \\
P<0.01\end{array}$ \\
\hline$d$ & 5.00 & 5.00 & & $d$ & 0 & 0 & $\begin{array}{l}c / b \\
P<0.01\end{array}$ \\
\hline$e$ & 2.91 & 2.92 & & $e$ & 0 & 0 & $\begin{array}{l}c / d \\
P<0.01 \\
c / e \\
P<0.05\end{array}$ \\
\hline \multicolumn{4}{|c|}{4 weeks } & \multicolumn{4}{|c|}{6 weeks } \\
\hline$a$ & 29.81 & 6.91 & $\begin{array}{l}a / d \\
P<0.01\end{array}$ & $a$ & 25.56 & 10.11 & $\begin{array}{l}a / d \\
P<0.01\end{array}$ \\
\hline$b$ & 3.99 & 2.05 & $\begin{array}{l}a / e \\
P<0.01\end{array}$ & $b$ & 4.43 & 2.58 & $\begin{array}{l}a / e \\
P<0.01\end{array}$ \\
\hline$c$ & 23.82 & 11.26 & $\begin{array}{l}b / d \\
P<0.01\end{array}$ & $c$ & 22.05 & 11.96 & $\begin{array}{l}b / d \\
P<0.01\end{array}$ \\
\hline$d$ & 0 & 0 & $\begin{array}{l}b / e \\
P<0.01\end{array}$ & $d$ & 0 & 0 & $\begin{array}{l}b / e \\
P<0.05\end{array}$ \\
\hline$e$ & 0 & 0 & $\begin{array}{l}c / d \\
P<0.01 \\
c / e \\
P<0.01\end{array}$ & $e$ & 0 & 0 & $\begin{array}{l}e / d \\
P<0.01 \\
c / e \\
P<0.01\end{array}$ \\
\hline \multicolumn{4}{|c|}{8 weeks } & \multicolumn{4}{|c|}{10 weeks } \\
\hline$a$ & 23.25 & 10.27 & $\begin{array}{l}a / d \\
P<0.05\end{array}$ & $a$ & 9.56 & 5.08 & $\begin{array}{l}b / e \\
P<0.05\end{array}$ \\
\hline$b$ & 8.33 & 4.11 & $\begin{array}{l}a / e \\
P<0.01\end{array}$ & $b$ & 9.33 & 3.94 & \\
\hline c & 11.55 & 3.38 & $\begin{array}{l}c / d \\
P<0.05\end{array}$ & $c$ & 3.55 & 1.88 & \\
\hline$d$ & 0.31 & 0.31 & $\begin{array}{l}c / e \\
P<0.05\end{array}$ & $d$ & 5.25 & 4.22 & \\
\hline$e$ & 0.27 & 0.27 & & $e$ & 1.25 & 1.12 & \\
\hline \multicolumn{4}{|c|}{12 weeks } & \multicolumn{4}{|c|}{14 weeks } \\
\hline$a$ & 10.13 & 4.83 & $\begin{array}{l}a / d \\
P<0.05\end{array}$ & $a$ & 4.74 & 3.19 & \\
\hline$b$ & 11.94 & 5.90 & $\begin{array}{l}a / e \\
P<0.05\end{array}$ & $b$ & 3.94 & 2.70 & \\
\hline$c$ & 5.50 & 2.73 & $\begin{array}{l}b / d \\
P<0.05\end{array}$ & $c$ & 5.86 & 3.74 & \\
\hline$d$ & 0 & 0 & $\begin{array}{l}b / e \\
P<0.01\end{array}$ & $d$ & 1.90 & 1.90 & \\
\hline$e$ & 0 & 0 & $\begin{array}{l}c / d \\
P<0.05 \\
c / e \\
P<0.05\end{array}$ & $e$ & 0.27 & 0.27 & \\
\hline \multicolumn{4}{|c|}{16 weeks } & \multicolumn{4}{|c|}{20 weeks } \\
\hline$a$ & 5.93 & 3.86 & $\begin{array}{l}b / d \\
P<0.05\end{array}$ & $a$ & 0 & 0 & \\
\hline$b$ & 2.72 & 1.39 & & $b$ & 0.31 & 0.31 & \\
\hline$c$ & 3.36 & 1.96 & & $c$ & 1.14 & 1.14 & \\
\hline$d$ & 0 & 0 & & $d$ & 0 & 0 & \\
\hline$e$ & 3.82 & 3.82 & & $e$ & 0 & 0 & \\
\hline \multicolumn{4}{|c|}{24 weeks } & & & & \\
\hline$a$ & 3.13 & 3.13 & $\begin{array}{l}b / e \\
P<0.05\end{array}$ & & & & \\
\hline$b$ & 6.78 & 3.98 & $\begin{array}{l}b / c \\
P<0.05\end{array}$ & & & & \\
\hline$c$ & 0 & 0 & & & & & \\
\hline$d$ & 0.60 & 0.60 & & & & & \\
\hline$e$ & 0 & & & & & & \\
\hline
\end{tabular}

${ }_{1} a:$ breast-fed, colonized infants; $b:$ bottle-fed, colonized infants; $c:$ breast-fed control subjects; $d$ : bottle-fed control subjects; $e$ : lysozyme-fed infants; $\bar{x}$ : arithmetic mean. For statistical evaluation the Fisher test [9] was used. 

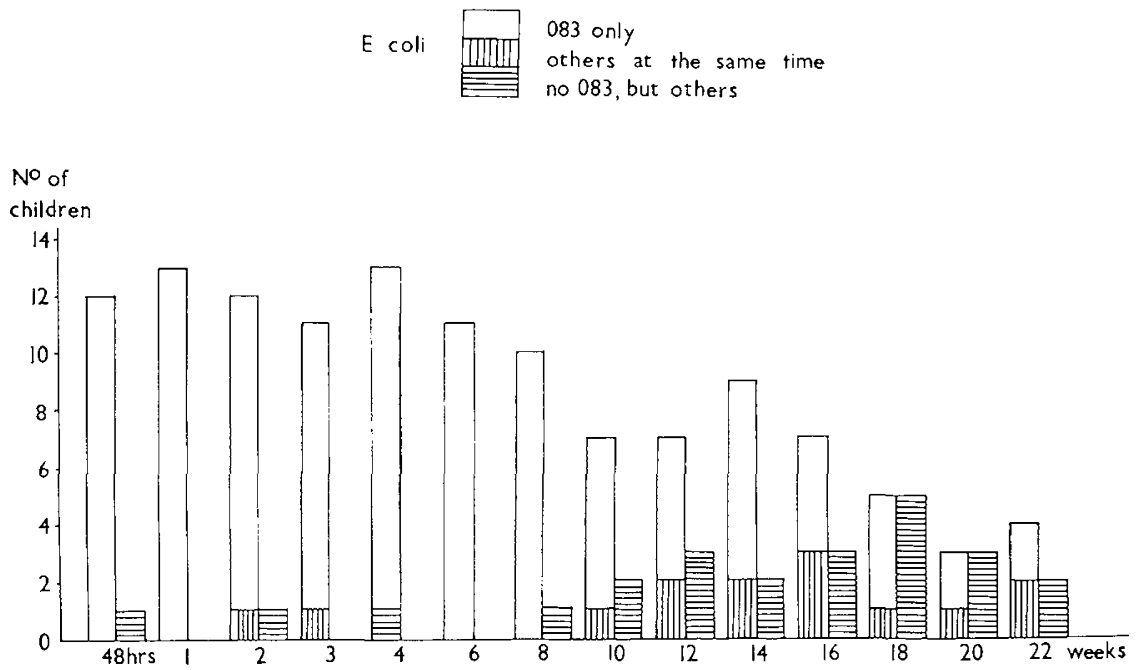

Fig. 1. Colonization of the intestine with Escherichia coli 083 and other E. coli strains (detection).

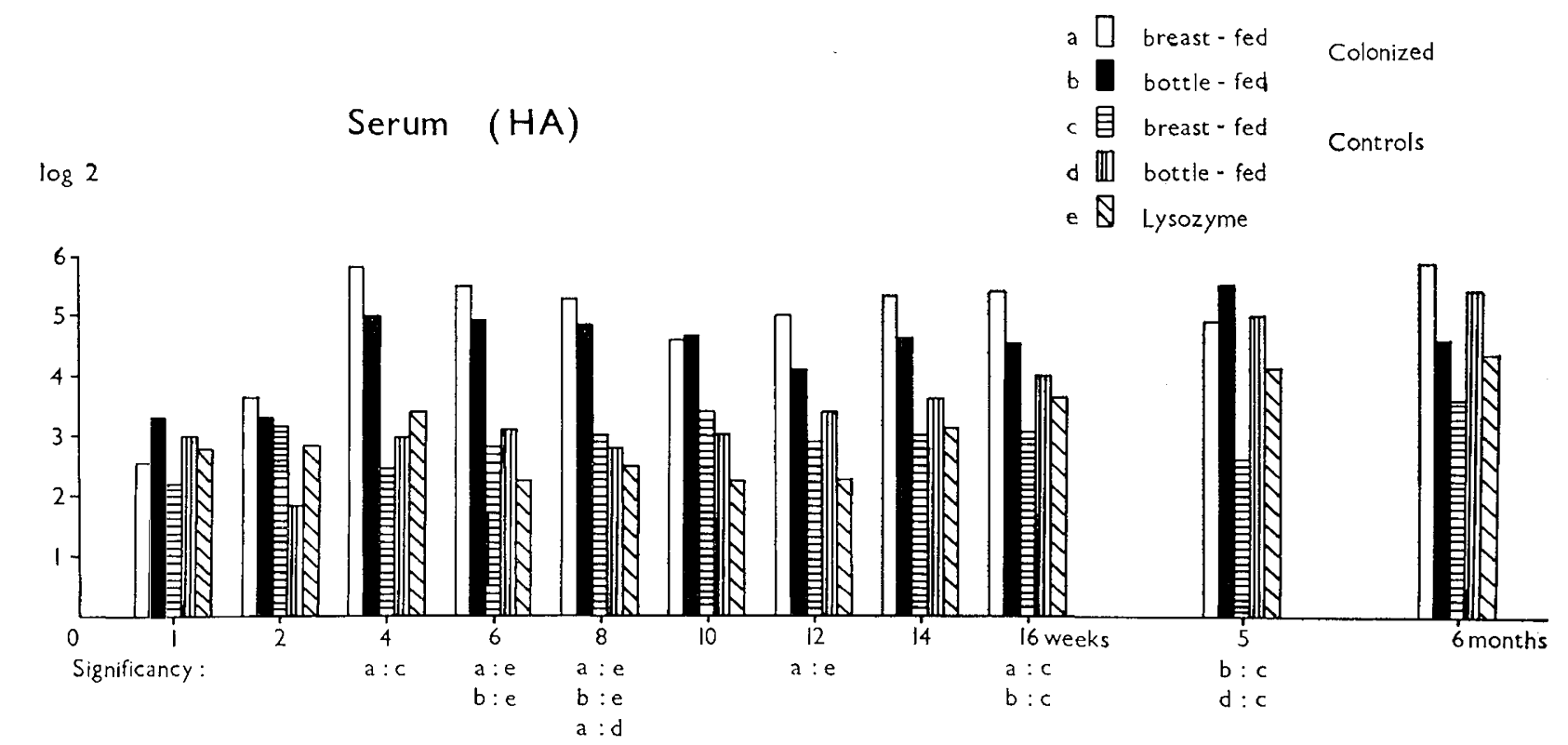

Fig. 2. Serum antibody against Escherichia coli 083.

weeks there was no difference in IgG among the groups (Fig. 4).

Serum IgA was low in the 1st week of life and increased gradually from the 4 th week in all groups of infants (Fig. 5).

Lysozyme did not influence the serum immunoglobulin levels. From the clinical observation a better stool quality was noticed.

Coproantibody formation was found to be significant at 4 weeks in the colonized, artificially fed group (Fig. 6). This maximum level of type 083 agglutinins persisted to 16 weeks and slowly declined at 6 months.
In breast-fed, colonized infants coproantibodies were detected from the lst to the 6th week and later declined gradually. No difference in the coproantibody response was observed in the artificially fed control and lysozyme-fed group.

IgM was detectable only in the artificially fed colonized group (Fig. 7). IgM was first found in this group at 4 weeks.

Stool IgA was present in elevated amount in both breast-fed groups at $1-8$ weeks of age (Fig. 8). The elevated IgA levels persisted in the breast-fed, colonized infants to 8 weeks, whereas the IgA level declined 

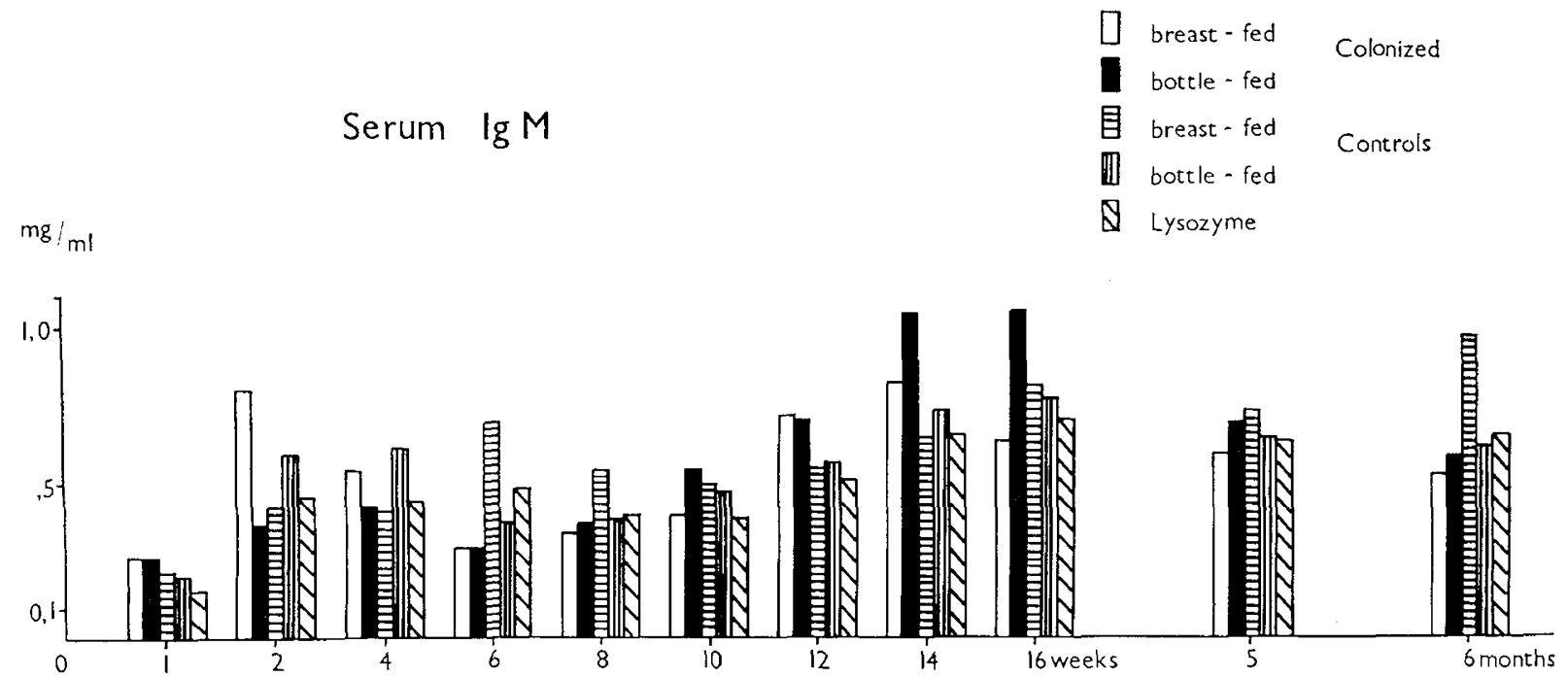

Fig. 3. Serum IgM levels.

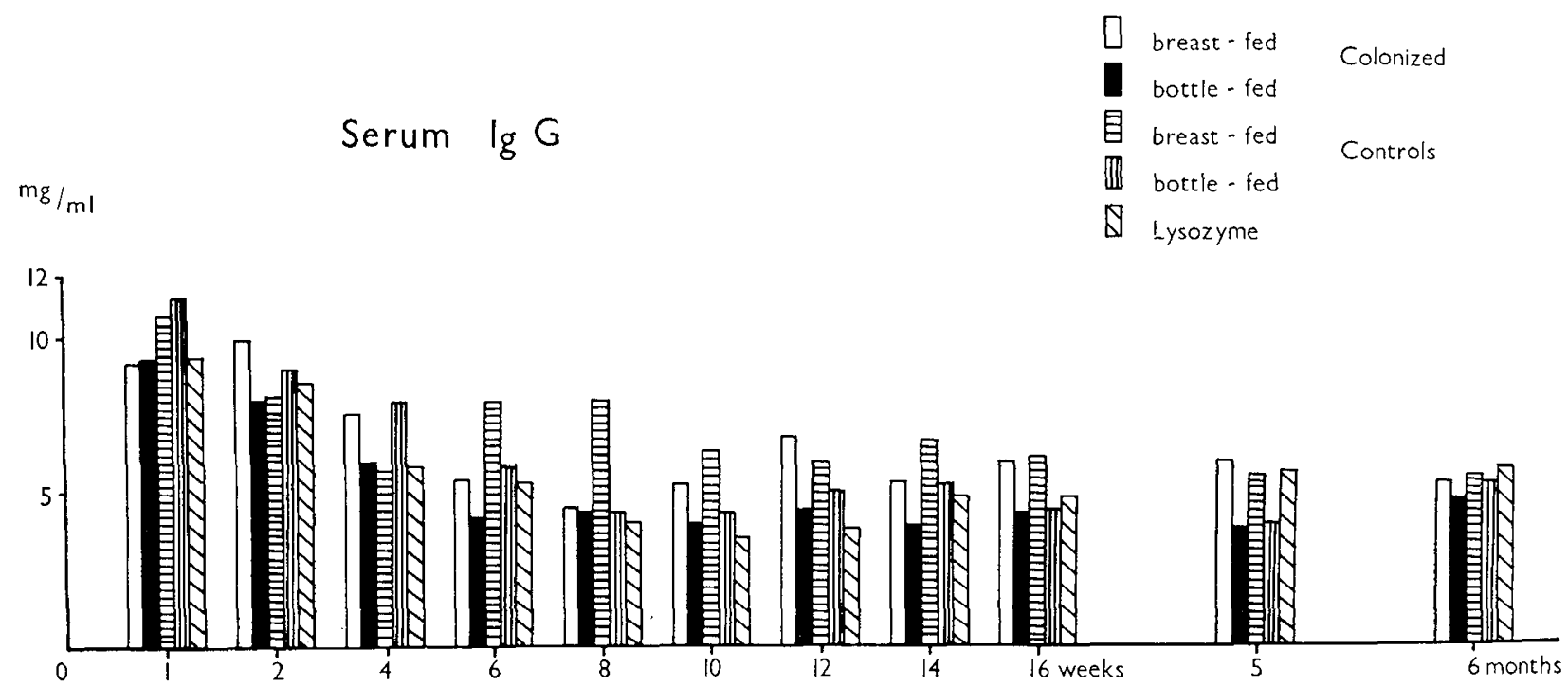

Fig. 4. Serum IgG levels.

in the breast-fed control subjects at that time. An increase in the IgA was detected in the colonized, artificially fed infants from 4 up to 12 weeks when compared with the artificially fed control subjects and the lysozyme-fed group.

\section{Discussion}

Each infant after birth becomes naturally colonized with microbes from the environment. The substitution of the randomly acquired intestinal flora by a tested nonpathogenic $E$. coli strain permits investigation of immune development and keeps the composition of the intestinal flora partly under control. All infants were kept under intensive health care and were in excellent health during the whole period of investigation. No gastrointestinal disorders were observed. Further evidence for the safety of colonization with $E$. coli 083 was the absence of detectable serum proteins in the stool without elevation of serum IgA in agreement with Schultze and Heremans [32]. We used the same nonenteropathogenic $E$. coli 083 strain for artificial colonization as in our previous work. In spite of a good knowledge of its biochemical and antigenic properties [19] it has not been explained why this particular E. coli strain colonizes the intestine so well and 


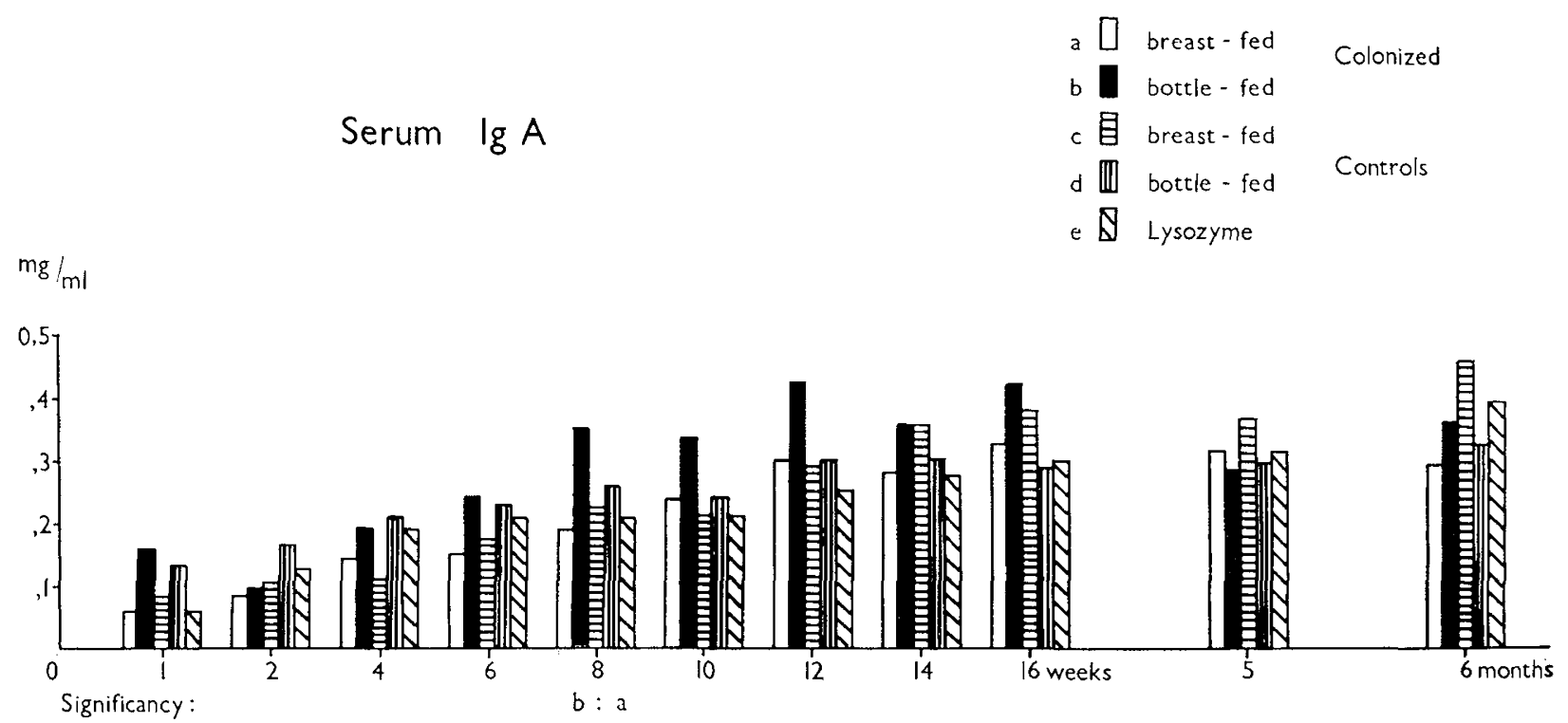

Fig. 5. Serum $\operatorname{Ig} \Lambda$ levels.

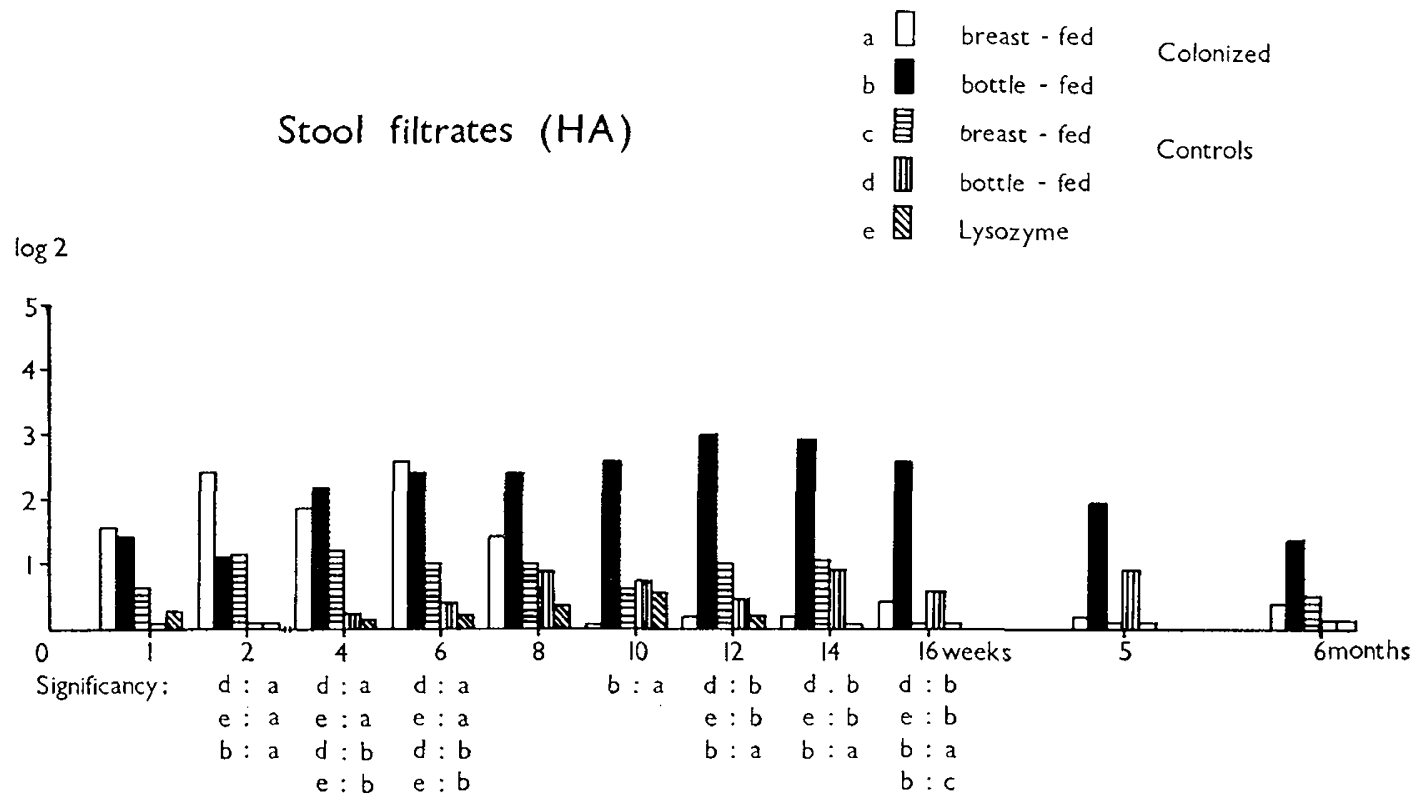

Fig. 6. Coproantibody levels in stool filtrates.

remains in preclominance for many weeks. Our experiences were also confirmed by Hanson [12], who used the same strain for colonization.

The serum antibody against $E$. coli 083 was significantly higher after 4 weeks in colonized, breast-fed infants and bottle-fed infants when compared with control groups. In colonized, bottle-fed infants, the antibody titer remained higher for 20 weeks and no difference could be detected later on. In breast-fed control subjects, however, the titer was low until the age of 20 weeks. This difference would be explained by a predominance of Lactobacillus bifidus in breast-fed infants and less contact with $E$. coli antigens than in formula-fed infants.

Furthermore, in lysozyme-fed infants, the serum antibody against the strain E. coli 083 was low when compared with formula-fed control subjects. We did not study whether lysozyme supported the growth of Lactobacillus bifidus. Hypothetically, such an influence could be suggested and in that case a lesser 

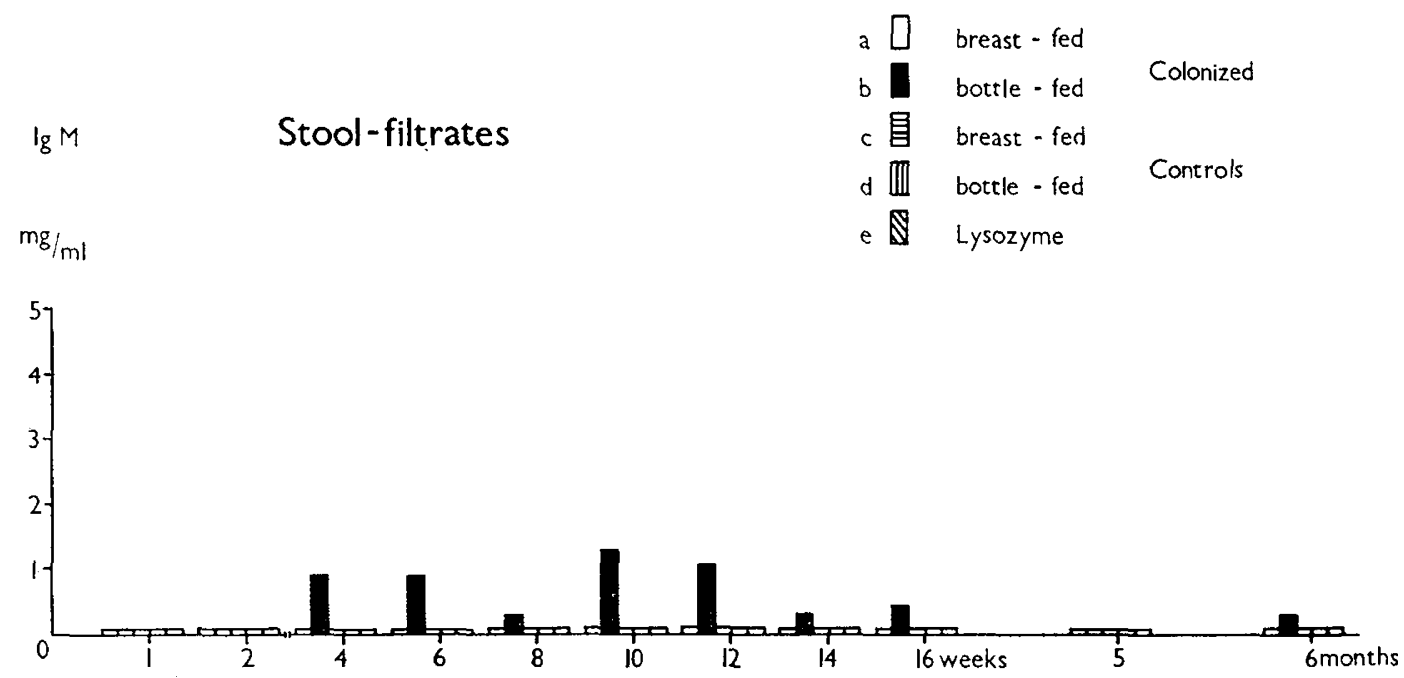

Fig 7 IgM levels in stool filtrates.

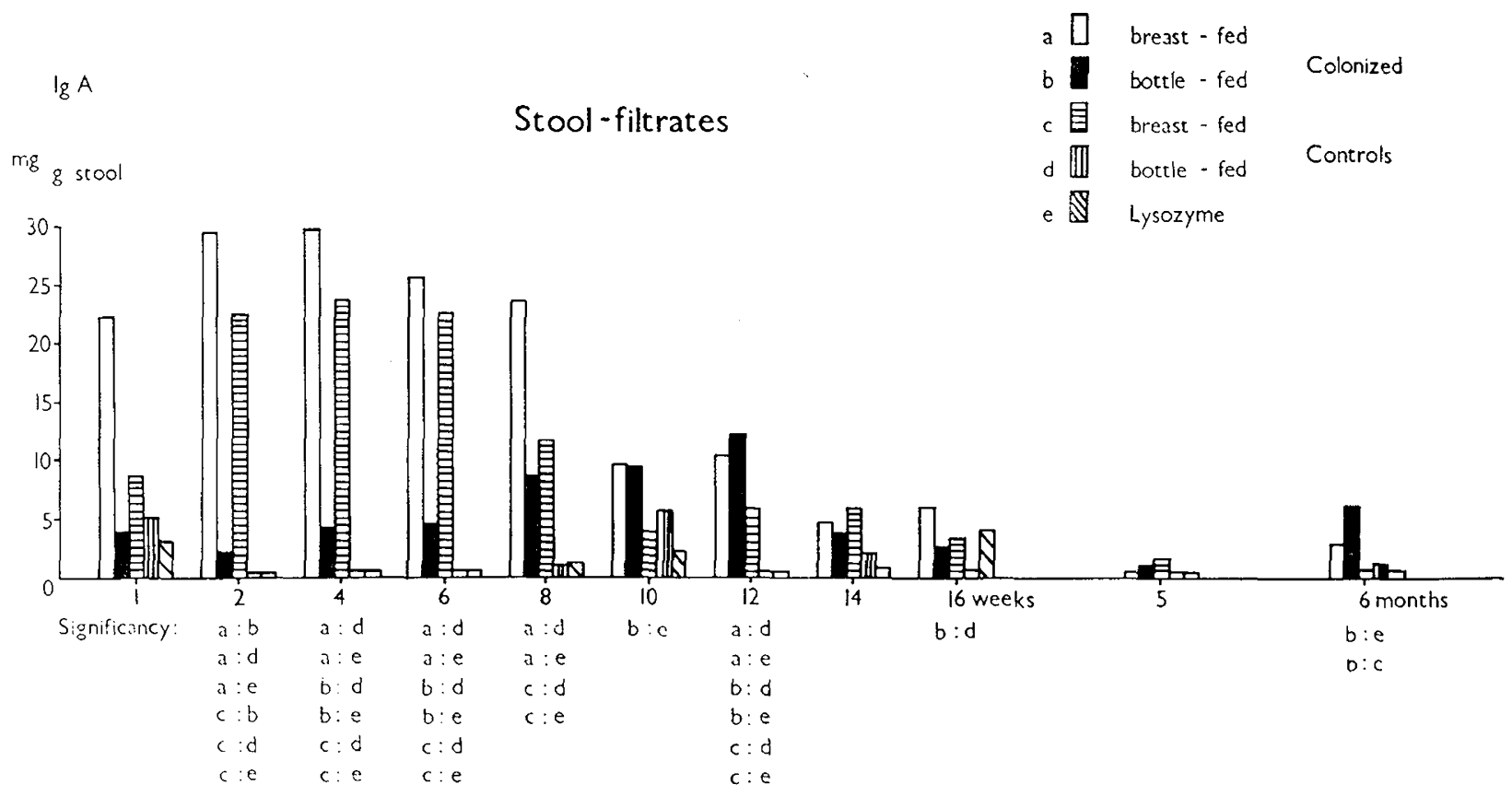

Fig. 8. Secretory IgA levels in stool filtrates.

amount of $E$. coli would colonize the intestine spontaneously.

Low titers of hemagglutinating antibody against $E$. coli 083 in sera of the control subjects can be explained by cross-reactions with common antigens of $E$. coli strains which colonize the intestine spontaneously.

Freter et al. [11] found only a slight increase of serum antibodies in cholera patients in comparison with healthy control subjects. He ascribes the main protective effect to coproantibodies produced locally in the intestine.
Antibodies against $E$. coli do not cross the placenta and, therefore, a newborn infant is not protected against $E$. coli infections. The early induction of antibodies against $E$. coli 083 achieved after artificial colonization might protect the infant against $E$. coli infections because of their numerous antigenic cross-reactions. However, it is difficult to prove this effect clinically.

Oral colonization of neonates with the nonenteropathogenic strain 083 resulted in the formation of coproantibodies to the 0 antigen in most subjects. Al- 
though the maximum titer of coproantibodies was the same in the two colonized groups, the breast-fed infants showed a peak antibody titer at 2 weeks which declined at 8 weeks. In contrast, the coproantibody formation in artificially fed and colonized infants occurred at 4 weeks but persisted until 16 weeks. The explanation for the differences in the immune response between the two colonized groups is that the breast milk antibody suppressed the formation of coproantibody in a manner similar to that described by Katz and Plotkin [14], who studied the inhibitory effect of breast feeding on oral polio vaccination.

However, the oral colonization with $E$. coli induced a local immune response even though a more rapid decline of coproantibodies occurred in the presence of maternal milk in the breast-fed group.

Another difference between the groups was the slightly elevated $\operatorname{IgM}$ level in stools of the colonized, artificially fed group. This finding indicates that a local active immune response occurred in artificially fed, colonized infants.

Colonization induced the formation of secretory IgA. This effect was masked in the breast-fed infants because of the passive transfer of this immunoglobulin from the maternal milk.

Oral immunization has been shown to confer protection against enteric infectious diseases. As early as 1922, feeding of inactivated Shigella to infants induced protection against dysentery caused by this organism [28]. This procedure was later confirmed by other workers using polio virus and Shigella vaccines [26, 29].

Other studies in man and laboratory animals have shown that oral immunization is the most effective route for the synthesis of high levels of coproantibodies $[7,10]$.

Adinolfi et al. [1] has shown that secretory IgA can exert a complement-dependent bactericidal effect only in the presence of lysozyme. Eddie et al. [7], who used highly purified rabbit immunoglobulins, showed that lysozyme potentiated the complement-dependent bactericidal activity of serum itself and of intestinal $\mathrm{IgG}$. The lack of interaction of lysozyme secretory IgA antibacterial antibodies in these latter experiments could have been due to a species difference or a IgG contamination of the IgA preparation used by Adinolfi et al. Wernet et al. [39] has suggested that coproantibodies promote phagocytosis of the microorganisms on a mucous membrane surface.

In our study, the feeding of lysozyme did not result in a statistically significant difference between the cop- roantibodies and intestinal immunoglobulins when compared with the artificially fed control group.

Colonization of neonates with $E$. coli 083 resulted in elevated coproantibody and secretory IgA levels, especially in the artificially fed infants. Breast-fed infants are partly protected against intestinal infectious diseases [24, 31]. Our results suggest that oral colonization of neonates with nonenteropathogenic $E$. coli may induce a better state of immunity for artificially fed infants.

\section{Summary}

The influence of oral colonization with nonenteropathogenic E. coli strain 083 and feeding with lysozyme in breast-fed and bottle-fed infants upon the production of immunoglobulins and antibodies in serum and stool filtrates were studied.

In colonized infants the strain $E$. coli 083 was detected in the stool from the 2nd day after oral administration and remained in predominance for up to 16 weeks. The serum antibody against E. coli 083 in. creased between the 4th week after colonization and remained higher until 16 weeks. At that age the anti. body level did not differ from the bottle-fed control group. In breast-fed control subjects, however, the titer remained low. IgG passively transferred from the mother decreased slowly and from the 12th week an increase, which was probably due to the infants' own production, was shown. In breast-fed control subjects, no decrease was noticed. IgA level went up gradually from the 4 th week in all groups of infants.

The colonization and lysozyme administration did not influence significantly the serum immunoglobulin levels.

Coproantibody formation was detected in colonized, artificially fed infants at 4 weeks and the maximum level persisted to 16 weeks. In breast-fed, colonized infants the coproantibody level was significantly higher between 2 and 6 weeks, when compared with control subjects.

IgM was detectable only in the artificially fed colonized group from the 4 th week up to 16 th week in low levels.

Secretory IgA level in breast-fed, colonized and control infants was high between 1 and 8 weeks. In bottle-fed, colonized infants the increase of IgA started from the 4th week and stayed significantly higher in the 6th, 12th, and 16th week when compared with control subjects.

No IgG was found in stool filtrates of any group. 
No difference in the coproantibody response was observed in the lysozyme-fed group as well as in the artificially fed control group.

The artificial colonization induced a formation of secretory IgA. This effect was masked in the breast-fed infants because of passive transfer of this immunoglobulin. The lack of IgA in bottle-fed infants was substituted by active formation caused by artificial colonization.

\section{References and Notes}

1. Adinolfi, M., Glynn, A. A., Lindsay, M., and Milne, C. M.: Serological properties of antibodies to Escherichia coli in human colostrum. Immunology, 10: 517 (1966).

2. BesreokA, A.: Local Immunization. (The Williams and Wilkins Company, Baltimore, 1927).

3. Burrows, W., Elliot, M. E., and Havens, I.: Studies on immunity to asiatic cholera. IV. The excretion of coproantibody in experimental enteric cholera in the guinea pig. J. Infect. Dis., 81: 261 (1947).

4. Crabiè, P. A., Bazin, H., Eyssen, H., and Heremans, J. F.: The normal microbial flora as a major stimulus for proliferation of plasma cells synthesizing IgA in the gut. Int. Arch. Allergy, 34: 362 (1968).

5. Crabiè, P. A., and Heremans, J. F.: The distribution of immunoglobulin-containing cells along the human gastrointestinal tract. Gastroenterology, 51: 3, 305 (1966).

6. Daragina, S., and Cocciante, B.: Abstracts of the 3rd International Symposium on the Lysozyme, p. 79, 1964.

7. Ednif, 1). S., Scrudrind, M. L., ANd Robbins, J. B.: The isolation and biologic activities of purified secretory IgA and IgG anti-Salmonella typhimuvium $\mathrm{O}$ antibodies from rabbit intestinal fluid colostrum. J. Immunol., 106 (1): 181 (1971).

8. FAHEY, J. L., AND MCKerveY, E.: Quantitative determination of serum immunoglobulins in antibody-agar plates. J. Immunol., 94: 84 (1965).

9. Fishre, R. A.: Statistical methods for rescarch workers. (Oliver-Boyd, Edinburgh, 1950).

10. Fretrer, R., and Ganginosa, E. J.: Oral immunization and production of coproantibody in human voluntecrs. J. Immunol., 91: 724 (1963).

11. Fretter, R., Mondal., A., Shrivastava, D., and Sunderman, F. W.: Coproantibody and serum antibody in cholera patients. J. Infect. Dis., 115: 83 (1965).

12. Hanson, L. A.: Personal communication.

13. Hanson, L. A., Borseen, R., Holmgren, J., Jodal, V., JohanSON, B. G., AND Kayser, B.: Secretory IgA. In: B. M. Kagan and E. R. Stiehm: Immunologic Incompetence, p. 39. (Year Book Medical Publishers, Chicago, 1971).

14. Katz, M., ANd Plotkin, S. A.: Oral polio immunization of the newborn infant: A possible method for overcoming interference by ingested antibodies. J. Pediat., 73: 267 (1968).

15. Kawnkami, K., Tatsumi, H., Tatsumi, M., and Kono, R.: Studies on poliovirus coproantibody. I. Neutralizing antibodies in feces of children following Sabin oral poliovirus vaccination. Amer. J. Epidemol., 83: 1 (1966).

16. Kellek, R., DWyer, J. P. W., AND D'Amodio, M.: Intestinal IgA neutralizing antibodies in newborn infants following poliovirus immunization. Pediartics, 43 (3): 330 (1969).
17. Keniy, J. F., Boesman, K. J., AND Michals, R. H.: Bacterial and viral coproantibodies in breast-fed infants. Pediatrics, 39 (2): $202(1967)$.

18. KoshindN, M. E., AND BUrrows, W.: Quantitative studies of the relationship between fecal and serum antibody. J. Immunol., 65: 93 (1950).

19. LANC, A.: Doctoral thesis, 1972.

20. LAx, I.: Artificial nourishment and lysozyme (Review). Lattante, 39: 16 (1968).

21. Lominoví, R., JoUja, V., AND LANC, A.: Influence of the intestinal flora on the development of immune reactions in infants. J. Bacteriol., 93: 197 (1967).

22. Lodinoví, R., Jouja, V., AND LANC, A.: Experimentelle Besiedlung des Darmtraktes von Neugeborenen mit dem E. coli Typ 083 und Untersuchungen über die Bildung von Antikörper. Z. Immunitactsforsch. Allergie Klin. Immunol., 137: 403 (1967).

23. LommoVÁ, R., AND W WGNYR, V.: Immunoglobulins and coproantibodies after oral colonization (E. coli). In: B. M. Kagan and E. R. Stiehm: Immunologic Incompetence, p. 61. (Year Book Medical Publishers, Chicago, 1971).

24. MATA, J. L.: Development of the indigenous intestinal flora of infants in health and discase. VIIIth International Congress of Nutrition, Praguc, 1969.

25. Neter, E., Westrhat, O., Lü̈meritz, O., ANd Gorzynski, E. A.: The bacterial hemagglutination test for the demonstration of antiborlies of Enterobacteriaccac. Ann. N. Y. Acad. Sci., 66: 141 (1956).

26. Ogra, P. L., Karzon, D. T., Righteland, F., and Maggillioray, M.: Immunoglobulin response in serum and secretion after immunization with live and inactivated poliovaccine and natural infection. New Engl. J. Mecl., 279: 893 (1968).

27. Prorman, P., AND Brobfrgir, O.: Lower gastrointestinal system. In: P. Miescher and H. S. Müller: Textbook of Inmunology, Vol. 2., p. 551. (Grune \& Stratton, New York, 1969).

28. RAFTTI, H., AND MAMsch, R.: Oral vaccination against Shigellosis by means of heat killed bacteria. Arch. Immunol. Ther. Exp., 16: 324 (1968).

29. Rnuss, K., Pusztai, S., Joó, I., Kétryi, I., and Máté, J.: Maintenance of artificial dyscntery immunity by oral vaccination in humans. Acta Microbiol. Acad. Sci. Hung., 1f: 153 (1967).

30. Scmpre, H.: The Analysis of Variance. A Wiley Publication in Mathematical Statistics. (John Wiley and Sons, New York, 1963).

31. Schner̆cans et al.: Alimentation cles prématurés au lait de femme at au colostrum. Alimentation du prémature, p. 176. $\mathrm{XXII}^{\mathrm{e}}$ congrès de l'Association des pédiatres de langue francaise, September 1-3, Strasbourg, 1969.

32. Schurtze, H. E., And Hfrrmans, J. F.: Molecular Biology of Human Proteins, Vol. I, p. 798. (Elsevier Publishing Company, New York, 1966).

33. Shm, B. S., Kanc, Y. S., Kim, W. J., Cho, S. H., and Lee, D. B.: Self-protective activity of colostral IgA against tryptic digestion. Nature, 222: 787 (1969).

34. Solomon, J. B.: Ontogeny of immunoglobulin synthesis. Foctal and Neonatal Immunology, Vol. 20, Chapt. 9, p. 190. (North-Holland Research Monographs Frontiers of Biology, Amsterdam-London, 1971).

35. Šterzl, J., AND Srlverstern, A. M.: Developmental aspects of immunity. Advan. Immunol., 6: 337 (1967).

36. Tomast, T. B., and Bienrenstock, J.: Secretory immunoglobulins. Advan. Immunol., 9: 1 (1968). 
37. Torikata, R., AND Imazumi, M.: Zum Unterschiede zwischen der Injections-und der oralen Immunisierung. Z. Immunitaetsforsch. Allcrgie Klin. Immunol., 94: 342 (1938).

38. Tourville, D., Adler, R., Brenenstock, J., And Tomasi, T. B.: The human secretory immunoglobulin system. Immunohistological localization of $\gamma \mathrm{A}$, SP, and lactoferrin in normal human tissues. J. Exp. Mcd., 129: 411 (1969).

39. Werner, H., Breu, J., KNop, J., AND Rowley, D.: Antibacterial action of specific $\operatorname{IgA}$ and transport of $\operatorname{IgM}, \operatorname{IgA}$, and $\operatorname{IgG}$ from serum into small intestine. J. Infect. Dis., $12 f(2): 223$ (1971).
40. Egg-white lysozyme tablets were kindly supplied by Socicta Prodotti Antibiotici, Milano, Italy.

41. Feminar, produced by the Czechoslovakian milk industry.

42. Sevac, Prague, Czechoslovakia.

43. Kindly supplied by Dr. J. B. Robbins, National Institutes of Health, Bethesda, Md.

44. Informed consent for publication of clinical data on the subjects reported herein has been granted by parties involved.

45. Requests for reprints should be addressed to: RAJA Lodinová, M.D., Institute for the Care of Mother and Child, Department of Pediatrics, Prague 4-Podoli, Czechoslovakia.

46. Accepted for publication February 27, 1973. 